\title{
THE RELATIONSHIP BETWEEN SELECTED VARIABLES AND CUSTOMER LOYALTY WITHIN AN OPTOMETRIC PRACTICE ENVIRONMENT
}

\author{
Tertius Van Vuuren: Department of Marketing Management, University of Johannesburg \\ Mornay Roberts-Lombard: Department of Marketing Management: University of Johannesburg \\ Estelle van Tonder: Department of Marketing Management, University of Johannesburg
}

Purpose: The purpose of the research that informed this article was to examine the relationship between customer satisfaction, trust, supplier image, commitment and customer loyalty within an optometric practice environment.

Problem investigated: Optometric businesses need to adopt their strategies to enhance loyalty, as customer satisfaction is not enough to ensure loyalty and customer retention. An understanding of the variables influencing loyalty could help businesses within the optometric service environment to retain their customers and become more profitable.

Methodology: The methodological approach followed was exploratory and quantitative in nature. The sample consisted of 357 customers who visited the practice twice or more over the previous six years. A structured questionnaire, with a fivepoint Likert scale, was fielded to gather the data. The descriptive and multiple regression analysis approach was used to analyse the results. Collinearity statistics and Pearson's correlation coefficient were also calculated to determine which independent variable has the largest influence on customer loyalty.

Findings and implications: The main finding is that customer satisfaction had the highest correlation with customer loyalty. The other independent variables, however, also appear to significantly influence customer loyalty within an optometric practice environment. The implication is that optometric practices need to focus on customer satisfaction, trust, supplier image and commitment when addressing the improvement of customer loyalty.

Originality and value of the research: The article contributes to the improvement of customer loyalty within a service business environment that could assist in facilitating larger market share, higher customer retention and greater profitability for the business over the long term.

Key words and phrases: Optometric practice, customer loyalty, customer retention, customer satisfaction, customer relationship management

\section{INTRODUCTION}

Loyalty is paramount for long-term success in the optometric services industry. The globalisation of competition, saturation of markets, and development of information technology have enhanced customer awareness and created a situation where long-term success is no longer achieved through optimised product, price and qualities (Kuusik, 2007:5). Rootman (2006:2) supports this view and cautions that fierce competition and ever-changing market conditions are forcing service businesses to adapt their business strategies. All industries are becoming more customer-orientated rather than product-orientated (Nyadzayo, 2010:19). This is the same in the optometry industry (Joubert, 2009:7).

Creating satisfied customers is critical in fostering customer retention (Marandi \& Harris, 2010:147149; Gil, Hudson \& Quintana,2006:47). However, satisfaction alone cannot be used as a measure to assess loyalty within the optometric industry. According to Kuusik (2007:11), customers who are satisfied defect to other providers of service more often than not, and much more needs to be done to establish customer loyalty than just a focus on customer satisfaction. Dillehay (2004:1) confirms this view and notes that customers within the optical industry specifically defect easily to other providers. His investigation has shown that $85 \%$ of customers who defect to other service providers were satisfied with the service received just before defecting.

It is suggested that optometrists should rather foster loyalty by focusing on building good relationships with their customers. The assumption is that strong, mutually beneficial relationships between service providers and clients build loyalty through repeat purchases, thus providing financial rewards for the business. This can be attributed to various factors. For instance, regular customers frequently visit the 

T. Van Vuuren,
M. Roberts-Lombard
E. van Tonder
The relationship between selected variables and customer loyalty within an optometric practice environment

service provider, hence they cost less to service; long-established customers tend to use more services and loyal customers may pay premium prices. Furthermore, retaining customers makes it difficult for competitors to enter the market or to increase their market share and loyal customers often refer new customers to the service provider, which is very beneficial, as there is no expenditure in gaining these new customers (Du Plessis, 2010:63; Kuusik, 2007:5; Rootman, 2006:36).

Several antecedents have been identified to create and influence customer loyalty. Boohene and Agyapong (2011:229-232) argue that while customer satisfaction is important, other factors such as switching costs, trust, customer relationships, corporate image of the provider, service quality, customer relationship management (CRM) strategies and communication also need to be investigated to truly understand the factors that influence customer loyalty. Both Bibb and Kourdi (2007:87-89) and Liang and Wong (2004:57-60) postulate that the main driver of loyalty is trust, while Yieh, Chiao and Chiu (2007:267-270) state that there is a positive relation between pricing strategies and customer loyalty. Peterson and Limbu (2009:193-195) note that empathy from sales staff positively influences satisfaction and loyalty, while Wang (2010:252-260) argues that there is a positive relationship between service quality, perceived value and customer loyalty. Helkkula and Kelleher (2010:44) support this view. Kuusik (2007:3-21), in contrast, contends that many of the antecedents of loyalty are in fact interlinked. These antecedents can be summarised as follows: satisfaction (expectation, satisfaction with product, satisfaction with service), trust (supplier, product and salesman), image (brand personality, goals and values of supplier) and commitment (termination cost, intimacy of relationship and importance of the product).

As far as could be ascertained, very little research has been conducted within the optometric industry to gain a better understanding of which of the factors, as summarised by Kuusik (2007:3-21), have a direct impact on customer loyalty within an optometric practice. An understanding of these variables, though, could help businesses within the optometric service environment to retain their customers and become more profitable. It is therefore essential for research to investigate which of these factors may be the building blocks for establishing customer loyalty within an optometric practice.

\section{OBJECTIVES}

Emanating from the research problem, the objectives of the survey were the following:

- To determine whether customer satisfaction, trust, commitment and supplier image influence customer loyalty within an optometric practice.

- To establish which of the four independent variables has the largest influence on customer loyalty within an optometric practice.

- To make recommendations regarding the influence of the four independent variables on the dependent variable customer loyalty within an optometric practice.

\section{THEORETICAL BACKGROUND}

Scholars have emphasised four key virtues that have been theorised in the relationship marketing literature, namely customer satisfaction (Nyadzayo, 2010; Kuusik, 2007). trust (Morgan \& Hunt 1994; Moorman, Deshpandè \& Zaltman, 1983), supplier image (Kuusik, 2007) and commitment (Ndubisi, 2007; Morgan \& Hunt 1994), Morgan and Hunt (1994) stipulate that trust and commitment are central to relationship marketing because they encourage marketers to work at preserving relationship investments by cooperating with exchange partners, resist attractive short-term alternatives in favour of the expected long-term benefits of staying with existing partners, and view potentially high-risk actions as being prudent because of the belief that their partners will not act opportunistically. Kuusik (2007:9) further stipulates that to transact with a provider, the customer usually needs to be able to identify with the business. This can not be done if the provider of service has an image which does not conform to the patient. Hence the provider needs to create an image, a process which is done through location, product, service, pricing policy, and all products which are believed to conform to the potential customer base. Nyadzayo (2010:125) and Kuusik (2007:9) argue that a direct connection exists between satisfaction and loyalty; satisfied customers become loyal and dissatisfied customers 


\begin{tabular}{l|l} 
T. Van Vuuren, & $\begin{array}{l}\text { The relationship between selected variables and customer loyalty } \\
\text { M. Roberts-Lombard }\end{array}$ \\
w. van Tonder &
\end{tabular}

move to another provider. They stipulate that supplier image specifically has not been explored to the same extent as trust, commitment and customer satisfaction, but are as important in the establishment and maintenance of long-term relationships with customers.

\section{Customer relationship building and loyalty}

Relationships are established through voluntary repeat business between a supplier and a customer where the behaviour is planned, co-operative and intended to continue the mutual benefit of both parties. An understanding of trust and commitment is required to build this long-term relationship. Businesses need to show customers that they are committed while offering customers the core service benefit. Should these issues be addressed correctly, it may lead to the customer developing long-term relations with the business, which in turn will create loyalty (Thompson \& Thompson, 2003:23-34). Customer loyalty can be defined as a customer's likelihood to choose a particular brand with reference to his or her past purchases. This behavioural definition of loyalty captures the outcomes of both attitudinal commitment and habitual buying. The term 'customer loyalty' is used to emphasise that loyalty is a characteristic of customers, rather than characteristics of brands (Zhang, Dixit \& Friedmann, 2010:128). Effective relationship-building strategies are vital in fostering customer loyalty within a business (Rootman, 2006:36).

\section{Factors affecting customer loyalty}

Customer satisfaction, trust, supplier image and commitment are relevant factors that could affect customer loyalty.

Customer satisfaction: Nyadzayo (2010:125) defines customer satisfaction as "the consumer's fulfilment response. It is a judgement that a product or service feature, or the product or service itself, provided a pleasurable level of consumption related fulfilment, including elements of under- or over fulfilment".

Customer satisfaction is influenced by expectations, perceived service and perceived quality $\mathrm{Hu}$, Kandampully \& Juwaheer, 2009:115-116). Expectations influence total satisfaction when the customer evaluates a product or service. Satisfaction is a customer's emotional response when evaluating the discrepancy between expectations regarding the service and the actual performance perception. This perception of performance is gained through the physical interaction with the business and the product and services of the business (Salami, 2005:239). Perceived quality is measured through recent service experiences that consist of two components, namely perceived product quality and perceived service quality. There is a direct link between perceived quality and total satisfaction (Balaji, 2009:5455). The customer first forms expectations based on needs, values, past experiences and extrinsic cues about the product. The perceived quality is based on those first expectations and the choice the customer made is then evaluated to determine satisfaction (Grounaris, Tzempelikos \& Chatzipanagiotou, 2007:68). Perceived value is the customer's overall assessment of the quality of a product based on the perception of what is received versus what is provided ( $\mathrm{Yu}$, Wu, Chiao \& Tai, 2005:712).

It should further be noted that although satisfaction is important, satisfied customers tend to defect easily. Research studies have shown that $60-80 \%$ of customers who defect to a competitor commented in the survey they were satisfied or very satisfied just prior to their defection (Kuusik, 2007:9; Dillehay, 2004:1). This clearly shows that other factors also have an impact on customer loyalty and need to be investigated in conjunction with the customer satisfaction element.

Trust: Du Plessis (2010:88) defines trust as follows: "Trust refers to one party believing that the other party will act in his best interest, that the other party is credible and that the other party has the necessary experience." A key aspect that is reflected in this definition of trust is credibility. Credibility affects the long-term orientation of a customer by reducing the perception of risk associated with opportunistic behaviour by the firm. Specifically, trust reduces the uncertainty in an environment where customers feel vulnerable, because they know they can rely on the trusted organisation (Aydin \& Ozer, 2005:146).

Trust is an important factor in affecting relationship commitment and customer loyalty. If one party trusts another, such a party is willing to develop a positive behavioural intention toward the other party. 

T. Van Vuuren,
M. Roberts-Lombard
E. van Tonder
The relationship between selected variables and customer loyalty within an optometric practice environment

Accordingly, when a customer trusts a business or brand, that customer is willing to form a positive buying intention towards the business. The relationship between customer trust and customer loyalty is supported by reciprocal arguments. When service providers act in a way that builds customer trust, the perceived risk with the service provider is reduced, thus enabling the customer to make confident predictions about the service provider's future dealings. Trust influences loyalty by affecting the customer's perception of congruence in values with the service provider, and such value congruence is significantly related to the customer's satisfaction and loyalty. Trust as an element of customer loyalty has an influence on the building of customer loyalty Du Plessis, 2010:91-92; Chen \& Xie,2007:64; Aydin \& Ozer, 2005:146).

Supplier image: Kuo and Ye (2009:752) define supplier image as "a perception developed from the interactions among the institute, personnel, customers and the community, and is an association with the institute's ability to position itself in the customer's mind".

Supplier image has two principal components: a functional and an emotional component. The functional component involves the logical and structural analysis of an institute's performance with the focus on the tangible characteristics that can be measured. The emotional component of a business is based on subjective characteristics, which include sentimental attachments (Alwi, 2009:2-3; Chang \& Tu, 2005:198; O'Loughlin, Szmigin \& Turnbul, 2004:219). Kuo and Ye (2009:752) identify three factors that influence the supplier image: corporate image, store image and credibility. Corporate image is related to the business as a member of society, hence it is viewed not only as a service and product provider, but in terms of how it contributes and influences the surrounding society in general. Store image is defined according to how the infrastructure of the business supports the requirements and needs of customers, which include factors such as the perception of product and services, policies and staff quality. Credibility is a measure of the business's ability to meet customer requirements such as professional expertise, service and product quality, and trust with regard to both service and ethical reliability.

The more positive the evaluations of service and product delivery, the higher the customer's perceived image of the business (Hoq, Sulatana \& Amin, 2005:75-77). Da Silva and Alwi (2008:125) argue that supplier image is an important antecedent of loyalty and that loyalty will develop depending on the favourability of supplier image formed. Friedman, Brown and Taran (2007:1) note that supplier image needs to be addressed by business as it can have both positive and negative consequences if not managed correctly. Customers need to know the supplier and its brands for the right reasons. Supplier image serves as an important factor influencing customer loyalty, and a favourable image can stimulate repeat patronage. Furthermore, it is essential to maintain and improve the image of the business if existing loyal customers are to stay loyal (Hu et al., 2009:117).

Commitment: Ibrahim and Najjar (2008:14) define commitment as "an exchange partner believing that an ongoing relationship with another is so important as to warrant maximum efforts at maintaining it; that is, the committed party believes the relationship is worth working on to ensure that it endures indefinitely".

A high level of commitment provides the context in which the customer and business can achieve individual and joint goals without fear of opportunistic behaviour because more committed partners will exert effort and balance short-term problems with long-term goal achievement. Higher levels of commitment are expected for relationship success (Cai \& Wheale, 2004:516-517). Commitment is a means by which to differentiate successful relationships from unsuccessful ones; hence strong relationships are built on the foundation of mutual commitment (Ibrahim \& Najjar, 2008:14).

Commitment is generally regarded to be an important result of good relational interactions and is affected by the customer's perception of the effort made by the seller. Commitment is fuelled by the ongoing benefits accrued to each partner in the relationship, through the fact that committed customers have a greater propensity to act because of their need to maintain their relationship commitment. When the proportion of commitment becomes more marked, it is clear to infer that the relationship on both sides becomes more stable. Subsequently, commitment is also an important variable in the measurement of customer loyalty (Du Plessis, 2010:96; Liang \& Wong, 2004:70-71). Commitment operates in the same manner as trust in that certain levels of commitment are required to initiate the relationship, and as the relationship evolves, so does the level of commitment. 

T. Van Vuuren,
M. Roberts-Lombard
E. van Tonder

Commitment exists through behavioural, attitudinal, affective and calculative components (Du Plessis, 2010:94-95; Davis-Sramek, Mentzer \& Stank, 2008:443-445; Evanshitzky \& Plassman, 2006:63).

From the background, problem statement and hypotheses it can be concluded that the relationship between customer satisfaction, trustwothiness, supplier image, commitement and customer loyalty need to be investigated as the relationships remain unexplored. Figure1.1 reflects the hypohesis and the relationship between the independent variable and the dependent variable. An independent variable is a variable that is expected to influence the dependent variable. These relationships are important as they can lead to increased customer loyalty for the business. It is the objective of this study to investigate this relationship. The study will further attempt to identify the degree of influence of the independent variables on the dependent variable.

Figure 1.1: Conceptual framework

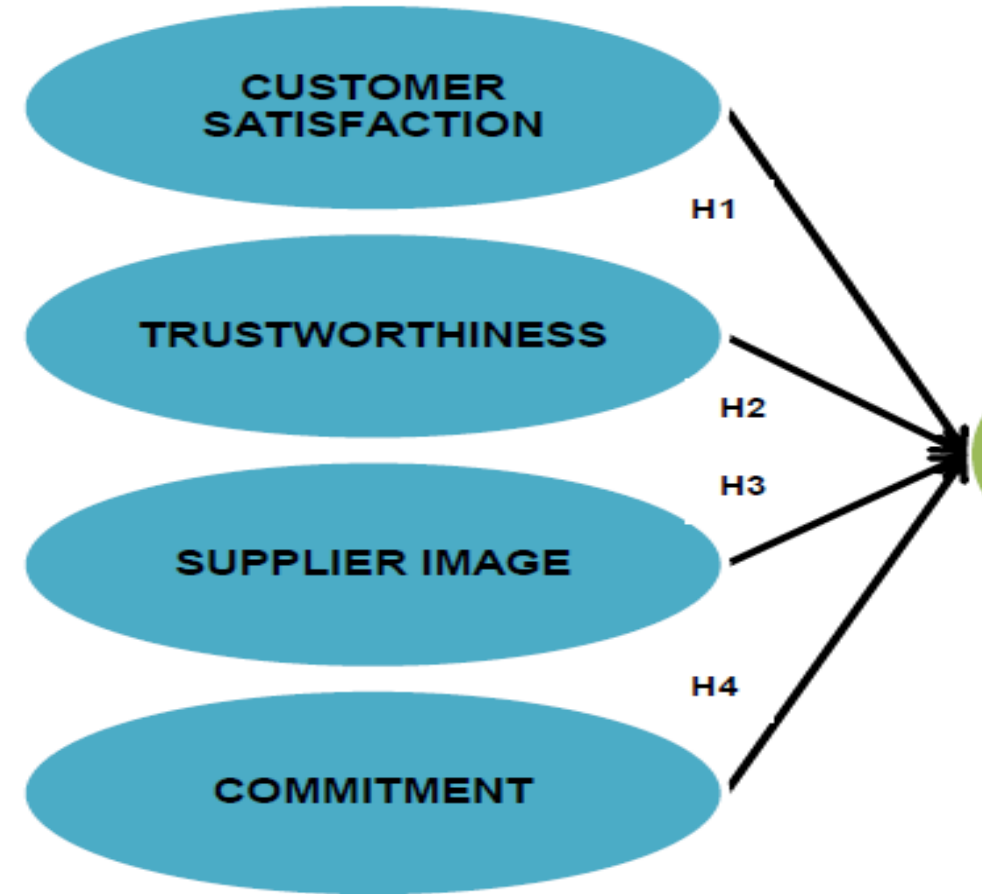

INDEPENDENT VARIABLES

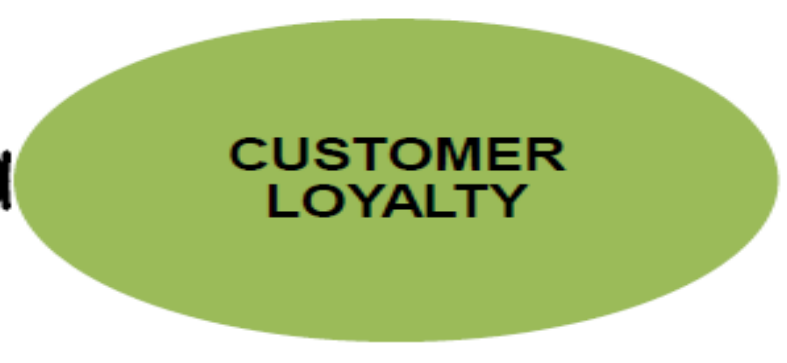

DEPENDANT VARIABLES

Source: Researcher's own construct

\section{PROBLEM STATEMENT}

The current post-recessionary economic climate, in which many businesses are liquidated, creates many challenges for service businesses. Existing customers need to be managed as assets, as it is more cost effective to service existing customers in relation to acquiring new customers (Zhang, Dixit \& Friedmann, 2010:128). Businesses need to build long-term relationships with customers to increase customer retention. These relationships and interactions are needed to create a loyal customer base. Ensuring a loyal customer base can have financial benefits, and ensure the long-term success for the business (Zhang et al., 2010:127). Literature notes that there are many factors businesses need to consider which influence the creation of customer loyalty (Du Plessis, 2010:85). However, the researcher could not find any studies that explored the elements which influence customer loyalty within the optometric industry. In addition, the researcher could not find any direct studies on the 

T. Van Vuuren,
M. Roberts-Lombard
E. van Tonder
The relationship between selected variables and customer loyalty within an optometric practice environment

relationship between customer satisfaction, supplier image, trust, commitment and customer loyalty within the optometric industry (Kuusik, 2007:11). This raises the question as to how the variables such as customer satisfaction, supplier image, trust, and commitment influence customer loyalty within the optometric industry. Understanding the variables which influence customer loyalty has become of great importance within the optometric practice under study. It is crucial to the business to gain a better understanding of the variables customer satisfaction, supplier image, trust, commitment, and to determine how these variables influence customer loyalty within the optometric industry. An understanding of consumer behaviour relating to consumer loyalty can be of strategic advantage and an eventual sustainable competitive advantage. There is a lack of information on the relationship between customer satisfaction, supplier image, trust, commitment and customer loyalty within the optometric industry. Therefore, these relationships need to be explored as these relationships could provide a means to improve customer loyalty within an optometric practice.

\section{HYPOTHESES}

The following hypotheses were tested in order to assist in meeting the research objectives:

- HA1: There is a relationship between customer satisfaction and customer loyalty within an optometric practice.

- HA2: There is a relationship between supplier image and customer loyalty within an optometric practice.

- HA3: There is a relationship between trust and customer loyalty within an optometric practice.

- HA4: There is a relationship between commitment and customer loyalty within an optometric practice.

\section{METHODOLOGY}

Following the literature findings, the empirical investigation was exploratory and quantitative in nature. The population comprised all the customers of an optometric practice (Wize Eyes Optometrist) who had visited the practice twice or more within the previous six years. (Permission was obtained to disclose the identity of the organisation.) A probability sampling approach was followed and the convenience sampling technique applied. The data was gathered over an eight-week period in 2011. During this time customers who visited the practice and who matched the sampling frame were asked to participate in the survey.

A structured questionnaire, with a five-point Likert scale, was used to gather the data. Respondents were provided with a self-administered questionnaire to complete. The questionnaire included self developed items, as well as items from questionnaires used in previous research such as Nyadzayo (2010), Du Plessis (2010) and Rootman (2006). Suitable scale items considered reliable and valid were obtained from the questionnaires of the abovementioned three researchers, but items were also developed from the literature review conducted to measure the influence of customer satisfaction, trust, supplier image and commitment on customer loyalty at an optometric practice. The constructs in the questionnaire were developed from the literature review and previous questionnaires by Nyadzayo (2010), Du Plessis (2010) and Rootman (2006). A total of 357 questionnaires were completed and could be used in the analysis. The questionnaire was pre-tested in a pilot study involving 20 customers who visited the practice and matched the sampling frame. The internal consistency reliability test was used to measure reliability. Validity was ensured by having the content of the questionnaire aligned with the research objectives.

The data obtained from the questionnaires was coded, captured and edited. The Statistical Package for Social Sciences (SPSS version 18) was used to analyse the results. The data obtained from the field was coded and captured in a statistical software package. A descriptive and multiple regression analysis approach was used to analyse the results. Collinearity statistics and Pearson's correlation coefficient were also calculated to determine which independent variable has the largest influence on customer loyalty. 


\begin{tabular}{l|l} 
T. Van Vuuren, & $\begin{array}{l}\text { The relationship between selected variables and customer loyalty } \\
\text { M. Roberts-Lombard }\end{array}$ \\
w. van Tonder &
\end{tabular}

\section{RESULTS}

Statistical techniques were applied to assess the reliability and validity of the survey and to obtain more clarity regarding the influence of the selected variables on customer loyalty within an optometric practice.

\section{Reliability}

According to Du Plessis (2010:12), when calculating Cronbach's alpha, results exceeding 0.60 will reflect the lower level of acceptability. The reliability statistics for the questionnaire are presented in Table 1:

Table 1: Reliability statistics

\begin{tabular}{|l|l|}
\hline Constructs & Cronbach's Alpha \\
\hline Customer satisfaction & 0.957 \\
\hline Trust & 0.911 \\
\hline Supplier Image & 0.895 \\
\hline Commitment & 0.913 \\
\hline Customer loyalty & 0.906 \\
\hline
\end{tabular}

It is evident from Table 1 that the Cronbach's alpha for all five constructs investigated is above the lower limit of acceptability, 0.60. This confirms that the measurement set that was used was reliable.

\section{Validity}

Validity can be attained by aligning the content of the questionnaire with the research objectives (Van Tonder \& Ehlers, 2011:164). Consequently, the following activities were performed to ensure validity and reliability:

- A self-administered questionnaire was designed, which was directly aligned with the research objectives.

- The necessary adjustments were made to the questionnaire, based on feedback obtained from the pilot study.

- A large sample size was used to increase the accuracy of the results.

- The expertise of STATKON (the Statistical Consultation Services) of the University of Johannesburg was employed to analyse the data gathered and to ensure the correct measurement of the results.

\section{Influence of the selected variables on customer loyalty}

Concerning the first research objective, multiple regression analysis was used to explain the relationship between the independent variables customer satisfaction, trust, supplier image, commitment and the dependent variable customer loyalty.

The results showed that all four independent variables, namely customer satisfaction, trust, supplier image and commitment, had a significant positive influence on the dependent variable customer loyalty. The research at hand relied on a $95 \%$ level of confidence; therefore a p-value equal to or less than 0.05 implies that the results are not subject to change, according to the Independent Sample TTest. More specifically, the relationship between customer satisfaction and customer loyalty is significant at $p=0.027$, the relationship between trust and customer loyalty is significant at $p=0.012$, the relationship between supplier image and customer loyalty is significant at $p=0.007$, and the relationship between commitment and customer loyalty is significant at $p=0.00$. The independent variables in the multiregression analysis explained $76.8 \%$ of the variance ( $R$ squared) in the dependent variable customer loyalty. It can be interpreted that $76.8 \%$ of a positive change in the level 


\section{T. Van Vuuren, \\ M. Roberts-Lombard \\ E. van Tonder}

of customer loyalty in Wize Eyes Optometrists is caused by customer satisfaction, trust, supplier image and commitment.

Given the above findings, it can be concluded that the hypotheses that were formulated should all be accepted. This implies that there is a relationship between the variables customer satisfaction, trust, supplier image and commitment and customer loyalty within the optometric practice investigated.

To give effect to the second research objective of establishing which of the four independent variables has the largest influence on customer loyalty, it is necessary to discuss the collinearity between the independent variables. Table 2 depicts the collinearity statistics at hand.

Table 2: Collinearity statistics

\begin{tabular}{|l|l|l|}
\hline \multirow{2}{*}{ Independent variables } & \multicolumn{2}{|l|}{ Collinearity statistics } \\
\cline { 2 - 3 } & Tolerance & VIF \\
\hline Overall_CustSatisf & .095 & 10.482 \\
\hline Overall_Trust & .124 & 8.043 \\
\hline Overall_Image & .389 & 2.570 \\
\hline Overall_Commit & .266 & 3.762 \\
\hline
\end{tabular}

Table 2 indicates that the correlation between the independent variables is statistically very high. Strong correlation between the different variables is good, but if high, it may also be an indicator that the researcher tested the same variable in different ways (Du Plessis, 2010:172). However, from the secondary research that was conducted it is evident that the different constructs tested are not identical. Furthermore, the primary research was conducted after researching previous related studies and using the measurement tools from those studies - thus explaining the high correlation. Literature also shows that historically there is a close correlation between the variables researched:

- Commitment is directly linked to the concept trust (Du Plessis, 2010:93).

- Commitment operates in the same manner as trust (Evanshitzky \& Plassmann, 2006:63).

- The result of trust is invariably sustained commitment and a virtuous cycle, with trust leading to greater effort, which in turn results in greater trust (Kuusik, 2007:27).

- A strong link exists between satisfaction, image and loyalty (Veloutsou, Daskou \& Daskou, 2004:120-126).

- Customer satisfaction acts as an intermediation between store image and customer loyalty (Chang \& Tu, 2005:196-210).

- Corporate image may influence customer satisfaction directly or indirectly (Lee, Kim \& Lim, 2006:79).

Pearson's correlation coefficient was also calculated to further investigate the correlation between the independent variables customer satisfaction, trust, supplier image, commitment and the independent variable customer loyalty. The findings confirmed that all the independent variables had a significant influence on the dependent variable customer loyalty. Customer satisfaction had the largest influence on customer loyalty when compared to supplier image, trust and commitment ( $R$ squared $=0.732 ; \quad p$-value $=0.855$ ). Trust ranked second in terms of its influence on customer loyalty, when compared to customer satisfaction, supplier image and commitment $(R$ squared $=$ 0.703; $p$-value $=0.835$ ). Supplier image had the third largest influence on customer loyalty when compared to customer satisfaction, trust and commitment $(R$ squared $=0.726 ; p$-value $=$ 0.852).Commitment had the lowest influence on customer loyalty after customer satisfaction, trust and supplier image $(R$ squared $=0.53 ; p$-value $=0.728)$. 

T. Van Vuuren,
M. Roberts-Lombard
E. van Tonder
The relationship between selected variables and customer loyalty within an optometric practice environment

In conclusion, from the findings above it is clear that customer satisfaction had the highest correlation with customer loyalty. The other independent variables, however, also correlated highly with customer loyalty. Therefore it is concluded that all four of the independent variables significantly influence customer loyalty within a selected optometric practice.

\section{MANAGERIAL IMPLICATIONS}

The findings of the conducted survey pointed to a number of managerial implications for optometric practices. Considering the fact that customer satisfaction had the largest influence on customer loyalty, Wize Eyes Optometrists would need to predominantly develop strategies and put procedures in place to enhance the satisfaction levels of their customers. To accomplish this objective, Wize Eyes Optometrists could for example lengthen their consultation time slots in order to gain a better understanding of the needs of their patients and address them more effectively. Wize Eyes Optometrists should also consider reducing the administrative workload placed on the optometrist to allow for more productive time with the customers. This strategy is important as the empirical findings have shown that the customers felt they could have received a more personalised service from the business.

Since the customers felt that their administrative complaints could have been managed in a more professional manner, Wize Eyes Optometrists would also need to provide more training initiatives for their support staff. They should be assisted in dealing with customer complaints more effectively and ensure they have the necessary skills required to act in a professional manner at all times. In addition, the business would need to ensure that the support staff are empowered and enabled to resolve the complaints from the customer effectively. Support staff should act as the representative for the business and propose and implement realistic solutions that would not only address the needs of the customer, but also be achievable from a business point of view.

Wize Eyes Optometrists would also need to pay attention to the other three variables investigated (trust, supplier image and commitment), as the analyses of the empirical results have proved that they too had an impact on the loyalty of customers.

Wize Eyes Optometrists ought to put procedures and infrastructure in place to build and sustain a trusting relationship with their customers. The empirical results showed that the patients at the practice were of the opinion that they felt a high level of trust towards the optometrist and support staff, but there were still some matters that would need to receive more attention. More specifically, they believed that the optometrists had the necessary skill and knowledge and that they acted in an ethical manner, but that greater care could be given in determining their personal needs. The majority of the respondents further indicated that they perceived the service delivery by administrative staff to be trustworthy and ethical. They believed that the administrative staff were willing to provide personal attention and have a professional approach. However, the respondents were of the opinion that administrative staff could improve their product knowledge.

Wize Eyes Optometrists would further need to sustain and improve their supplier image in order to create a higher level of customer loyalty. The respondents felt confident in the brand of Wize Eyes Optometrists and indicated that they trusted the business to provide them with quality products and service. However, it became clear from the empirical results that there were certain aspects which could still be improved. For example, the customers felt that a modification in the appearance of the practice could possibly enhance the image of the business. Accordingly, it is recommended that Wize Eyes Optometrists upgrade the layout of their practice and consider a more modern atmosphere. It is also suggested that the furniture in the reception area be replaced to improve the comfort for customers who need to wait for the optometrist. Wize Eyes Optometrist would in addition need to continually analyse trends in the optometric market and ensure that the business does not fall behind their competitors in their appeal and appearance.

Finally, Wize Eyes Optometrists would also need to introduce new initiatives to ensure their patients are truly committed to the practice and will not seek better services elsewhere. It became evident from the empirical results that the customers viewed their interactions with the support staff as an important aspect when considering the continuation of their relationships with the practice. Wize Eyes Optometrists could perhaps focus on social bonding tactics which could assist in improving 

T. Van Vuuren,
M. Roberts-Lombard
E. van Tonder
The relationship between selected variables and customer loyalty within an optometric practice environment

relationship commitment. It is suggested that employees with good interpersonal skills be recruited and training initiatives be introduced in order to develop social bonding skills for both the optometrists and the administrative staff. Wize Eyes Optometrists would also need to pay attention to their staff turnover to ensure that effective relationships between staff and customers are maintained.

\section{CONCLUSION}

Market and technological challenges as well as intensification in competition have created pressure for businesses within the South African marketplace. This situation also applies to the optometric market. Several practices are struggling to maintain and sustain sales. To assist in alleviating the problem, relationships with customers must be formed. The assumption is that strong relationships which are mutually beneficial to service providers and clients build loyalty through repeat purchases, which has financial rewards for the business. Consequently, the objective of our survey was to gain more insight into the factors that have an influence on customer loyalty within the optometric service environment.

At the initial stage of our investigation we discovered that Kuusik (2007:3-21) made a valuable contribution to the literature in his summary of the antecedents that may affect loyalty, namely customer satisfaction, trust, supplier image and commitment. This notion was confirmed in the empirical findings in the study reported in this article. It became evident in our study that all four the independent variables had a significant influence on whether patients will remain loyal towards the practice. This implies that Wize Eyes Optometrists can improve customer loyalty by enhancing customer satisfaction, trust, supplier image and commitment towards customers. These factors and their managerial implications, as mentioned in this article, would subsequently need to be incorporated into the relationship-building strategies of optometric practices. Special attention would also need to be given to customer satisfaction as it was determined that this factor had the largest influence on customer loyalty. Customer loyalty could then lead to customer retention which would result in greater profitability for the business and sustainability in the future.

The authors recommend that further research be done to examine the four factors surveyed in more depth (and on a larger scale) to assist optometric practices in South Africa to survive and grow their businesses. It would also be interesting to determine whether the same set of variables would influence customer loyalty in other business sectors in South Africa.

To conclude: the research reported in this article represents an exploratory approach to investigate the factors influencing customer loyalty within an optometric practice in South Africa. The findings of the survey, although limited in scope, contribute to the improvement of customer loyalty within a service business environment and could lead to larger market share, higher customer retention and greater profitability for the business.

\section{REFERENCES}

Alwi, S.F.S. 2009. "Online Corporate Brand Images and Consumer Loyalty", International Journal of Business \& Society, vol. 10, no. 2, pp. 1-19.

Aydin, S. \& Ozer, G. 2005. How switching costs affect subscriber loyalty in the Turkish mobile phone market: An exploratory study. Journal of Targeting, Measurement \& Analysis for Marketing, 14(2):141-155.

Balaji, M.S. 2009. Customer satisfaction with Indian mobile services. IUP Journal of Management Research, 8(10):52-62.

Bibb, S. \& Kourdi, J. 2007. "Chapter 7: Building customer trust" in Marshall Cavendish Limited, pp. 87-105. 
T. Van Vuuren,

M. Roberts-Lombard

E. van Tonder

Boohene, R. \& Agyapong, G.K.Q. 2011. Analysis of the Antecedents of Customer Loyalty of Telecommunication Industry in Ghana: The Case of Vodafone (Ghana), Canadian Center of Science \& Education.

Cai, Z. \& Wheale, P. 2004. Creating sustainable corporate value: A case study of stakeholder relationship management in China. Business \& society review (00453609), 109(4):507-547.

Chang, C. \& Tu, C. 2005. Exploring store image, customer satisfaction and customer loyalty relationship: Evidence from Taiwanese hypermarket industry. Journal of American Academy of Business, Cambridge, 7(2):197-202.

Chen, Y. \& Xie, J. 2007. Cross-market network effect with asymmetric customer loyalty: Implications for competitive advantage. Marketing science, 26(1):52.

Da Silva, R.V. \& Alwi, S.F. 2008. "Online corporate brand image, satisfaction and loyalty", Journal of Brand Management, vol. 16, no. 3, pp. 119-144.

Davis-Sramek, B., Mentzer, J.T. \& Stank, T.P. 2008. Creating consumer durable retailer customer loyalty through order fulfillment service operations. Journal of Operations Management, 26(6):781797.

Dillehay, S.M. 2004. "Ways to Improve Patient Loyalty", Review of Optometry, vol. 143, pp. 1-8.

Du Plessis, L. 2010. Customer relationship management and its influence on customer loyalty at Liberty Life in South Africa, University of Johannesburg.

Evanschitzky, H. \& Plassmann, H. 2006. Affective and Calculative Commitment as Antecedents of Customer Loyalty, American Marketing Association.

Friedman, D.C., Brown, T.A. \& Taran, Z. 2007. Specialty store expertise as a driver of satisfaction and share of wallet. The international review of retail, distribution and consumer research, 21(4):375389.

Gil, S.M., Hudson, S. \& Quintana, T.A. 2006. "The Influence of Service Recovery and Loyalty on Perceived Service Quality: A Study of Hotel Customers in Spain", Journal of Hospitality \& Leisure Marketing, vol. 14, no. 2, pp. 47-68.

Grounaris, S.P., Tzempelikos, N.P. \& Chatzipanagiotou, K. 2007. "The Relationships of CustomerPerceived Value, Satisfaction, Loyalty and Behavioral Intentions", Journal of Relationship Marketing, vol. 6 , no. 1, p. 63.

Helkkula, A. \& Kelleher, C. 2010. "Circularity of customer service experience and customer perceived value", Journal of Customer Behaviour, vol. 9, no. 1, pp. 37-53.

Hoq, M.Z., Sulatana, N. \& Amin, M. 2005. "The Effect of Trust, Customer Satisfaction and Image on Customers' Loyalty in Islamic Banking Sector", South Asian Journal of Management, vol. 17, no. 1, pp. 70-93.

Hu, H., Kandampully, J. \& Juwaheer, T.D. 2009. "Relationships and impacts of service quality, perceived value, customer satisfaction, and image: an empirical study", Service Industries Journal, vol. 29, no. 2, pp. 111-125. 
T. Van Vuuren,

M. Roberts-Lombard

E. van Tonder

Ibrahim, H. \& Najjar, F. 2008. "Relationship Bonding Tactics, Personality Traits, Relationship Quality and Customer Loyalty: Behavioral Sequence in Retail Environment", ICFAI Journal of Services Marketing, vol. 6, no. 4, pp. 6-37.

Joubert, M. 2009. Deregulation in the South African optometry industry. 2009, 1(2009):1-86.

Kuo, Y. \& Ye, K. 2009. "The causal relationship between service quality, corporate image and adults' learning satisfaction and loyalty: A study of professional training programmes in a Taiwanese vocational institute", Total Quality Management and Business Excellence, vol. 20, no. 7, pp. 749-762.

Kuusik, A. 2007. "Affecting customer loyalty: do different factors have various influences in different loyalty levels?", University of Tartu - Faculty of Economics \& Business Administration Working Paper Series, , no. 58, pp. 3-29.

Lee, C., Kim, S. \& Lim, J. 2006. "The Role of Corporate Image in the NCSI Model", Journal of International Consumer Marketing, vol. 19, no. 1, pp. 7-34.

Liang, C.C.L. \& Wong, W.W.W. 2004. "Integrative research into the financial services industry in Taiwan: Relationship bonding tactics, relationship quality and behavioural loyalty", Journal of Financial Services Marketing, vol. 10, no. 1, pp. 65-83.

Marandi, E. \& Harris, J. 2010. The impact of perceived service provider empathy on customer loyalty: Some observations from the health and fitness sector. Managing leisure, 15(3):214-227.

Morgan, R.M. \& Hunt, S.D. 1994. The Commitment-Trust Theory of Relationship Marketing. Journal of Marketing, 58:20-38, July.

Moorman C., Despandé R. \& Zaltman G. 1993. Relationships between Providers and Users of Market Research: The Role of Personal Trust. Marketing Science Institute, Cambridge, MA.

Ndubisi, N.O. 2007. Relationship marketing and customer loyalty. Marketing intelligence \& planning, 25(1):98-106.

Nyadzayo, M. 2010. The mediating role of customer relationship management on customer retention at selected motor vehicle dealership in the Buffalo City Municipality, University of Fort Hare, South Africa.

O'Loughlin, D.D.O., Szmigin, I.I.S. \& Turnbull, P.P.T. 2004, Branding and relationships: Customer and supplier perspectives. Journal of Financial Services Marketing, 8(3):218-230.

Peterson, R.T. \& Limbu, Y. 2009. The convergence of mirroring and empathy: Communications training in business-to-business personal selling persuasion efforts. Journal of Business-to-Business Marketing, 16(3):193-219.

Rootman, C. 2006. The influence of customer relationship management on the service quality of banks, Nelson Mandela Metropolitan University.

Salami, M.P. 2005. Impact of customer relationship management (CRM) in the Iran banking sector. International Journal of Organizational Innovation, 2(1):225-251.

Thompson, N.J. \& Thompson, K.E. 2003. Can marketing practice keep up with Europe's ageing population? European Journal of Marketing, 43(11/12):1281-1288. 


\begin{tabular}{l|l} 
T. Van Vuuren, & The relationship between selected variables and customer loyalty \\
M. Roberts-Lombard & within an optometric practice environment \\
E. van Tonder &
\end{tabular}

Van Tonder, E. \& Ehlers, L. 2011. Factors threatening the survival of independent financial advisers in their organisational life cycle: An exploratory study. South African Journal of Economic and Management Sciences, 14(2):155-169.

Veloutsou, C.C.V., Daskou, S.S.D. \& Daskou, A.A.D. 2004. "Are the determinants of bank loyalty brand specific?", Journal of Financial Services Marketing, vol. 9, no. 2, pp. 113-125.

Wang, C. 2010. "Service quality, perceived value, corporate image, and customer loyalty in the context of varying levels of switching costs", Psychology and Marketing, vol. 27, no. 3, pp. 252-262.

Yieh, K., Yu-Ching Chiao \& Ya-Kang Chiu 2007. Understanding the antecedents to customer loyalty by applying structural equation modeling. Total Quality Management \& Business Excellence, 18(3):267-284.

Yu, C.J., Wu, L., Chiao, Y. \& Tai, H. 2005. "Perceived quality, customer satisfaction, and customer loyalty: the case of lexus in Taiwan", Total Quality Management and Business Excellence, vol. 16, no. 6, pp. 707-719.

Zhang, J., Dixit, A. \& Friedmann, R. 2010. "Customer Loyalty and Lifetime Value: An Empirical Investigation of Consumer Packaged Goods", Journal of Marketing Theory \& Practice, vol. 18, no. 2, pp. 127-140. 